\title{
Isabelle Caneva, Gülgün Köroğlu (eds.). Yumuktepe, A Journey Through Nine Thousand Years
}

\section{Astrid Nunn}

\section{(2) OpenEdition}

1 Journals

\section{Édition électronique}

URL : http://journals.openedition.org/abstractairanica/41531

DOI : 10.4000/abstractairanica.41531

ISSN : 1961-960X

Éditeur :

CNRS (UMR 7528 Mondes iraniens et indiens), Éditions de l'IFRI

\section{Référence électronique}

Astrid Nunn, «Isabelle Caneva, Gülgün Köroğlu (eds.). Yumuktepe, A Journey Through Nine Thousand Years », Abstracta Iranica [En ligne], Volume 34-35-36 | 2017, document 18, mis en ligne le 15 juillet 2016, consulté le 02 octobre 2020. URL : http://journals.openedition.org/abstractairanica/41531 ; DOI : https://doi.org/10.4000/abstractairanica.41531

Ce document a été généré automatiquement le 2 octobre 2020.

Tous droits réservés 


\section{Isabelle Caneva, Gülgün Köroğlu (eds.). Yumuktepe, A Journey Through Nine Thousand Years}

\section{Astrid Nunn}

\section{RÉFÉRENCE}

Isabelle Caneva, Gülgün Köroğlu (eds.). Yumuktepe, A Journey Through Nine Thousand Years. Istanbul, 2010, 133 p., de nombreuses ill.

1 Le site de Yumuktepe est situé à la périphérie de Mersin, sur la côte méditerranéenne turque en Cilicie. Ce site a été habité du Néolithique jusqu'au Moyen Âge. La couche du $\mathrm{VI}^{\mathrm{e}}$ s. av. J.-C. est bien marquée par de la céramique grecque de divers horizons: céramique attique à vernis noir, amphores de Chios et des îles égéennes.

\section{AUTEURS}

\section{ASTRID NUNN}

Université de Munich 